\title{
Disturbance to Myristica swamps: Influence on Specific Gravity and Fibre Length of an Endemic and Endangered Tree Species of Western Ghats
}

\author{
B. Tambat ${ }^{1 *}$, N. Rajaskekar Murthy ${ }^{2}$, K. N. Muniswamy Gowda ${ }^{3}$, G. N. Chaithra ${ }^{1}$, Anil K. Sethy ${ }^{4}$ and M. Mahadev Murthy ${ }^{2}$ \\ ${ }^{1}$ Dept. of Crop Physiology, ${ }^{3}$ Dept. of Entomology, College of Agriculture, UAS-B, Hassan (573 225), India \\ ${ }^{2}$ Dept. of Forestry and Environmental Science, UAS, GKVK, Bangalore (560 065), India \\ ${ }^{4}$ Indian Wood Science and technology (IWST-ICFRE), Malleshwaram, Bangalore (560 003), India
}

\author{
Corresponding Author \\ B. Tambat \\ e-mail: btambat@yahoo.com
}

\author{
Article History \\ Article ID: AR1935 \\ Received in 09 ${ }^{\text {th }}$ December, 2018 \\ Received in revised form 25 $5^{\text {th }}$ February, 2019 \\ Accepted in final form 28 ${ }^{\text {th }}$ February, 2019
}

\begin{abstract}
Gymnacranthera canarica (King) Warb is an important tree species associated with Myristica swamps in the Western Ghats. The species is endemic to Western Ghats, India and economically important as fruit mace is used as spice. It is distributed all along the Western Ghats and already listed as threatened. It represents obligate swampy species and helps to understand the response of swampy species to disturbances. In this study an attempt was made to assess the influence of disturbance on swampy species wood specific gravity and fibre length. Using increment borer wood core samples were collected from selected locations in central Western Ghats. The samples were processed in the laboratory and wood specific gravity and fibre length was assessed. Then it was compared across the less disturbed and highly disturbed swamps at six locations. The results indicated that in all the six locations specific gravity decreases with increased level of disturbance to swamps. However, the results were significant at only two locations namely Thorme and Sampaje. The frequency distribution of specific gravity values was positively skewed for the less disturbed swamps whereas it was negatively skewed for highly disturbed swamps. The fibre length had also showed similar pattern. In conclusion our study indicates that disturbance to swamps alters the wood specific gravity and fibre length of swamp associated tree species. Our finding would help in developing long term strategies and action plans for conservation of swamps and its constituent species.
\end{abstract}

Keywords: Myristicaceae, swampy, disturbance, specific gravity, fibre length, Western Ghats, wood

\section{Introduction}

The Western Ghats of India shelters several unique ecosystems, one such example is presence of Myristica swamps. Myristica swamps, belongs to the class of freshwater swamps and usually occur at lower altitudes in evergreen forests. They possess unique species composition and behave like islands even though surrounded by forest vegetation (Tambat et al., 2006; 2014). These ecosystems, as their name indicates are dominated by members of ancient family Myristicaceae. The species such as Gymnacranthera canarica, Myristica fatua var. magnifica etc are exclusively associated with these swamps. Besides, these swamps also harbor several rare, endemic, economically important and threatened plant species (Vasudeva et al., 2001; Ganesan, 2002). These swamps serve as the perennial water source to many wild animals during summer and also facilitate the ground water recharge (Brown et al., 1979; Wharton and Brinson, 1979). Since, swamps occur at lower altitude and possess water throughout the year, they form ideal habitat for cultivation of areca, paddy and other commercial crops in Western Ghats. Presently, at many places the water flow from swamps has been diverted for agricultural and allied purposes. Many tree species associated with Myristica swamps posses various structural and anatomical modifications perhaps to suit the waterlogged swampy habitat (Vasudeva et al., 2001; Tambat et al., 2014). However, with increased demand for land and water once, undisturbed Myristica swamps are now being disturbed and fragmented in Western Ghats (Champion and Seth, 1968, Chandran et al., 1999, Chandran and Mesta, 2001; Tambat et al., 2014). Consequently, growth and survival of several tree species obligate to swamps has been affected (Nair and Daniel, 1986; Tambat et al., 2005; 2014; Chaithra et al., 2014).

Among the various characters of tree species, wood growth and property appears to be the key feature that helps to understand the tree adaptations to changing environmental conditions. A wood property has been noticed throughout the world (Zobel, 1983) and therefore, the causes of the 
change must be known. In order to use wood efficiently, the variation patterns within trees, among trees within the species and among species must be understood (Zobel and Van Buijtenen, 1989). Vijendra et al., (1992) for the first time made microscopic structure analysis of Indian Myristicaceae members and described genus Myristica possesses diffused porous wood. Among the various tree characters, wood specific gravity is an important physical characteristic. That is often correlated with most mechanical properties of wood (Izekor et al., 2010). Wood specific gravity indicates the amount of actual wood substance present in a unit volume of wood (Zobel and Jett, 1995). It is influenced by the cell wall thickness, the cell diameter, the early-wood to latewood ratio and the chemical content of the wood (Cave and Walker, 1994). Research has shown that it is a highly heritable character. However, environmental conditions under which a given species develops also influence wood growth and properties. Wood fibres another important property of wood. They have been extensively used in the modern composite industry due to their specific characteristics. Modern technologies for modification of wood fibres to enhance physical and mechanical properties are going on (e.g. surface functionality and tensile strength). Fibres are the natural composite structures in which cellulose fibrils are held together by lignin and hemicelluloses. Thus, in this study an attempt was made to understand and compare the variations in specific gravity and wood fibre of an obligate swampy in less disturbed and highly disturbed swamps in central Western Ghats. Our finding would help to improve the understanding about tree species and thereby helps in management of obligate swampy species in Western Ghats, India.

\section{Materials and Methods}

\subsection{Study site}

The study was carried out in the Western Ghats of peninsular India, one of the 35 Mega-biodiversity hot spots of the world (Myers, et al., 2000). The variability in the precipitation and topographic diversity generates a wide variety of vegetation types. It has wet evergreen and semi-evergreen forests on the western side and at high altitudes, while it harbors dry deciduous and scrub forest on the eastern slopes and lowlands (Jha et al., 2000). Through field surveys in the central Western Ghats six ideal locations namely Makutta, Sampaje, Kathlekhan, Thorme, Darbejaddi and Ithalimane were selected. Enough care was taken while selecting the locations to avoid heterogeneities (Figure 1).

2.2. Classification of swamps as less disturbed and highly disturbed

At each locations data on various threat parameters of swamps were collected by following a method described by Tambat et al. (2012) and threat index was computed for each swamp. Afterwards, swamps were classified as less disturbed and highly disturbed ones (Table 1).
Table 1: Threat index values of selected swamps across the locations

\begin{tabular}{llcc}
\hline & Location & \multicolumn{2}{c}{ Threat index values } \\
\cline { 3 - 4 } Sl. No. & & Less disturbed & Highly disturbed \\
\hline 1. & Makutta & 6.11 & 12.32 \\
2. & Sampaje & 10.47 & 17.44 \\
3. & Thorme & 9.12 & 19.73 \\
4. & Kathlekhan & 8.96 & 15.67 \\
5. & Darbejaddi & 8.62 & 19.35 \\
6. & Ithalimane & 9.15 & 14.26 \\
\hline
\end{tabular}

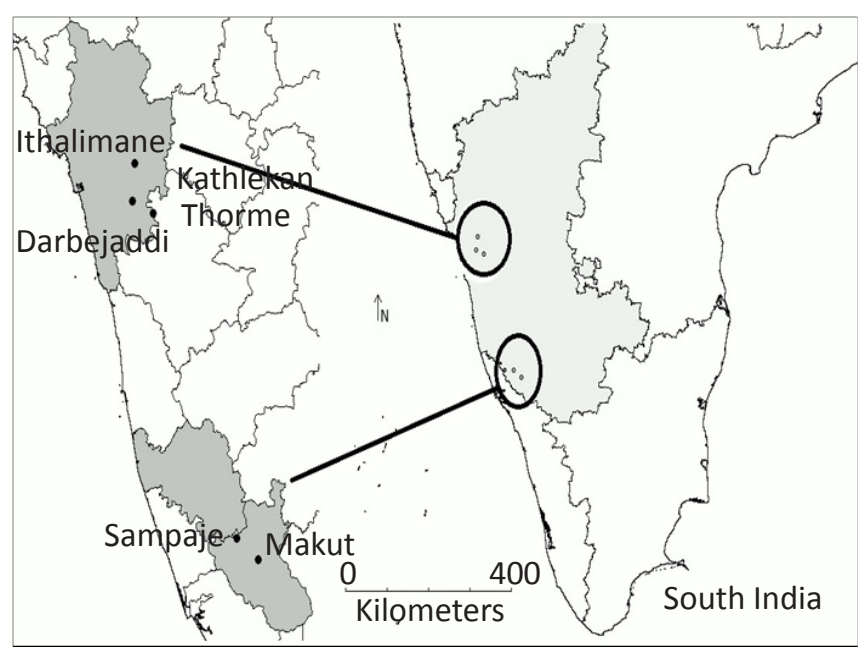

Figure 1: Specific study sites in Karnataka state, central Western Ghats, India

\subsection{Selection of species}

Among the various species associated with swamps, the Gymnacranthera canarica (King) Warb was selected for this study. Mainly, it is distributed all along the Western Ghats and also listed as threatened (Anonymous, 2000). The species is endemic to Western Ghats, India (Ramesh and Pascal, 1997) and economically important as fruit mace is used as spice. It represents obligate swampy species and helps to understand the response of swampy species to disturbances. Thus, Gymnacranthera canarica was selected as an ideal candidate for this study.

\section{4. Core collection}

Wood core of Gymnacranthera canarica trees were collected using increment borer (Hagloff, Sweden; bit length 40 cms, 5.15 core and two threaded). Three replications were maintained for each swamp.

\subsection{Specific gravity}

Two cores (opposite directions) were collected from each tree and three replications were maintained for each swamp. The wood core samples collected from the trees were brought to the laboratory. The wood core samples were cut from pith to 
periphery and the specific gravity was measured by following Maximum Moisture Content Method (Smith, 1954).

\subsection{Wood fibre}

Wood core sample were divided (into pith, middle and periphery) and macerations were carried by Schultz's method. Small slices of wood was taken from rings in a test-tube and boiled in water till the slices settled down in water. After discarding the water from test tube, a small quantity of $30 \%$ nitric acid and a few crystals of Potassium Chlorate were added. The test tube was warmed gently, after the splinters assume a white ragged appearance, the maceration was stopped by filling the test tube with cold water. The material was washed several times in running water and fibre length was measured using microscope (Leica Image Analysis System). All the measures were in accordance with the procedure recommended by the International Association of Wood Anatomists (Anon, 1989). Measurements were made on screen using a computer interfaced with a microscope through a video camera using the (Quantimet $500+$ ) software in the interactive measurement mode. After selecting the calibrated respective objective lens of the microscope anatomical parameters were measured. Counting the number of fibers per $\mathrm{mm}^{2}$ per field of view using $2.5 \mathrm{x}$ lens, microscope interfaced with a video monitor. Using ten fields of view the mean fibre length was calculated.

\subsection{Analysis}

The specific gravity and fibre length values of wood core samples namely less and highly disturbed swamps were compared using $t$-test (Snedecor and Cochran, 1967). Further, mean and frequency distribution of values for each category of swamps (less and highly disturbed) was also developed by pooling all the values in each category from different study sites. The distribution pattern was compared using a Kolmogorov - Smirnov test (Snedecor and Cochran, 1967).

\section{Results and Discussion}

Myristica swamps are one of the unique and threatened ecosystems of the Western Ghats, India. They are classified them as "Littoral and Swamp forest types" under the subgroup 4C "Tropical Freshwater Swamp Forests. They have high watershed value and occur at lower altitudes in evergreen forests. They serve as source of water to many animals during summer. Besides, they also form the ideal sites for cultivation of commercial areca palm and paddy. Therefore, many swamps have been progressively encroached and destroyed as a result area, covered by swamps has declined drastically in the Western Ghats. At many places the water from Myristica swamps have been diverted for agricultural purposes. Thus, many tree species associated with swamps are threatened. The influence of disturbance of specific gravity of an endemic and endangered tree species namely G. Canarica has be studied and results have been discussed.

3.1. Specific gravity of wood core samples in less disturbed and highly disturbed swamps

The specific gravity of $G$. canarica wood core ranged from 0.339 to 0.570 . The mean specific gravity was decreased with increased level of disturbance to swamps. The mean specific gravity for less disturbed swamps was $0.462 \pm 0.06$ whereas for highly disturbed swamps, it was $0.424 \pm 0.06$. The specific gravity of wood core sample was also compared between the swamps across each location and details are given in Table 2 . Among the six locations, only Thorme and Sampaje showed

\begin{tabular}{|c|c|c|c|c|c|c|}
\hline \multirow{2}{*}{ SI. No. } & \multirow[t]{2}{*}{ Location } & \multicolumn{2}{|c|}{ Less disturbed (LD) } & \multicolumn{2}{|c|}{ Highly disturbed (HD) } & \multirow{2}{*}{$\begin{array}{c}\text { Statistics } \\
\text { (T-test) }\end{array}$} \\
\hline & & Range & Mean $\pm S D$ & Range & Mean $\pm S D$ & \\
\hline 1. & Makutta & $0.361-0.417$ & $0.392 \pm 0.020$ & $0.352-0.427$ & $0.379 \pm 0.026$ & NS \\
\hline 2. & Sampaje & $0.451-0.550$ & $0.495 \pm 0.031$ & $0.339-0.404$ & $0.375 \pm 0.022$ & $\mathrm{t}=8.15, p<0.00$ \\
\hline 3. & Thorme & $0.508-0.578$ & $0.539 \pm 0.024$ & $0.459-0.547$ & $0.503 \pm 0.027$ & $\mathrm{t}=2.66, p<0.02$ \\
\hline 4. & Kathlekhan & $0.366-0.418$ & $0.396 \pm 0.017$ & $0.355-0.412$ & $0.387 \pm 0.023$ & NS \\
\hline 5. & Darbejaddi & $0.479-0.562$ & $0.524 \pm 0.028$ & $0.453-0.571$ & $0.506 \pm 0.045$ & NS \\
\hline 6. & Ithalimane & $0.389-0.462$ & $0.429 \pm 0.028$ & $0.353-0.445$ & $0.396 \pm 0.030$ & NS \\
\hline \multicolumn{2}{|c|}{ Over all mean } & $0.361-0.578$ & $0.462 \pm 0.065$ & $0.339-0.571$ & $0.424 \pm 0.064$ & $\mathrm{t}=2.71, p<0.008$ \\
\hline
\end{tabular}

statistically significant difference and the remaining four locations it was found non-significant.

Many environmental factors affect wood but the one most commonly cited is the moisture regime. Nicholls (1967) indicated that factors that are associated with moisture availability are important and influence on specific gravity in Pinus pinaster. He suggested wood quality can be improved through proper management of growing conditions. Gilmore
(1968) studied the trees species gravity across the slope and reported that trees at the bottom of slope or places where more rainfall was preserved possess a lower wood specific gravity than tree at the top of hill. Sluder (1970) reported that tree species that are subject to drought situation tend to increase their specific gravity by minimizing wood density. Suzuki (1999) measured wood properties for trees in lowland Dipterocarp in west Kalimantan. He measured the specific 
gravities and water contents of the wood including bark. Results showed wide range of specific gravities and suggested that forest had high diversity in wood properties. Josefina (1987) measured the specific gravity of 220 woody species and compared these two groups using a Student $t$-test. He studied both tropical rainforest and tropical deciduous forest tree species. Josefina revealed that woods from the dry deciduous forest tend to be much heavier than those from the rainforest and suggested moisture level influences wood specific gravity. Ferraz et al. (2011) also showed that there was a considerable effect of moisture deficiency on in Eucalyptus wood properties. Further he indicated that effect of moisture stress varies with the species.

In the present study, the specific gravity was expected to be higher in the disturbed sites as disturbance affect the micro climate and reduces the water level. However, the results were not as per the expectations. The results indicated that specific gravity of a Gymnacranthera canarica an endemic and endangered tree species of Western Ghats decreases with increased level of disturbance. However the results were significant at only two locations, namely Thorme and Sampaje. In majority (four) of the locations it was same (statistically not significant), indicating disturbance has no influence of specific gravity.

\subsection{Frequency distribution of specific gravity}

Frequency distribution of specific gravity values for each category of swamp was computed. The frequency distribution of specific gravity was positively skewed for the less disturbed swamps whereas it was negatively skewed to highly disturbed swamps indicating specific gravity decreases with increased level of disturbance to swamps (Figure 2). The frequency distribution of specific gravity for two categories of swamps compared using KS test, which indicated that distribution pattern is statistically different for two categories of swamps.

Frequency distribution indicated specific gravity varies across the two categories of swamps. The pattern suggested that specific gravity increased in disturbed swamps. The

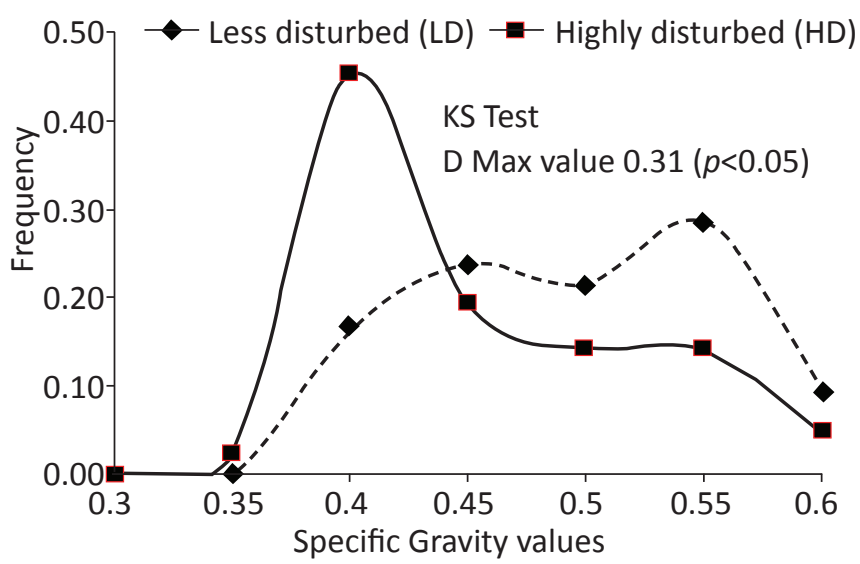

Figure 2: Frequency distribution of specific gravity values of Gymnacranthera canarica wood core samples between the two categories of swamps (KS-test; $p<0.05$ ). pattern indicated that less disturbed swamps have peak and less variance. However, the disturbed sites the values are distributed all along the axis without peak value.

Several parameters influenced by the disturbance to swamps have been studied, but the influence on growth and wood properties has been rarely studied. Earlier studies have indicated that swamps possess different physicochemical properties and microclimate. Further, the property changes with disturbance (Ponnamperuma, 1984; Varghese and Menon, 1999; Tambat et al., 2014). Although wood specific gravity is considered as an important trait that is directly connected with biomass production (Keays, 1971) and also considered less susceptible to decay (Schmidtling and Amburgey, 1982) has not been studied yet in swamps. Many factors of site, climate, geographic location, and species affect the specific gravity wood. Further, it is also determined to a large extent by the elevation, aspect, slop, latitude, soil type, stand composition and spacing (Schmidtling and Amburgey, 1982).

Perhaps the results indicated that disturbance could affect the species composition and regeneration but influence on wood property of a swamp adapted tree may take longer time. It means the water level has not changed to an extent that can affect the wood growth in trees. Further, the time required to alter the specific wood gravity of swampy species may be longer and then the time taken to change the species composition. Thirdly the level of disturbance varies across the swamps, thus degree to which the disturbance has occurred may also play as role. The correlation of the specific gravity with the level of disturbance of the swamp areas indicates that Thorme and Sampaje have suffered higher level of disturbance as compared to the other four locations resulting in significant difference in the specific gravity. In conclusion our study indicates that disturbance alters wood specific gravity in swampy species. Further long term studies are needed to signify the influence of disturbance on wood specific gravity of swamp adapted tree species.

\subsection{Fibre length of Gymnacranthera canarica wood core samples in less disturbed and highly disturbed swamps}

The fibre length of wood core samples were measured following Schultz's method. The average fibre length across the two categories of swamps was found to significantly different (Figure 3). The fibre length of wood core sample and its segments (Pith, Middle and Periphery) across the locations are given in Table 3. The minimum length of fibres from all the locations was $1001.49 \mu \mathrm{m}$ and maximum length was $2184.90 \mu \mathrm{m}$. Further, the results indicated that there is no significant difference in fibre length in all the locations (Table 3). Interestingly, there was significant difference observed in the periphery region from all the locations. Perhaps the region more influenced by the recent years disturbances (Table 4).

\subsection{Frequency distribution of Fibre length}

Frequency distribution of fibre length values for each category 


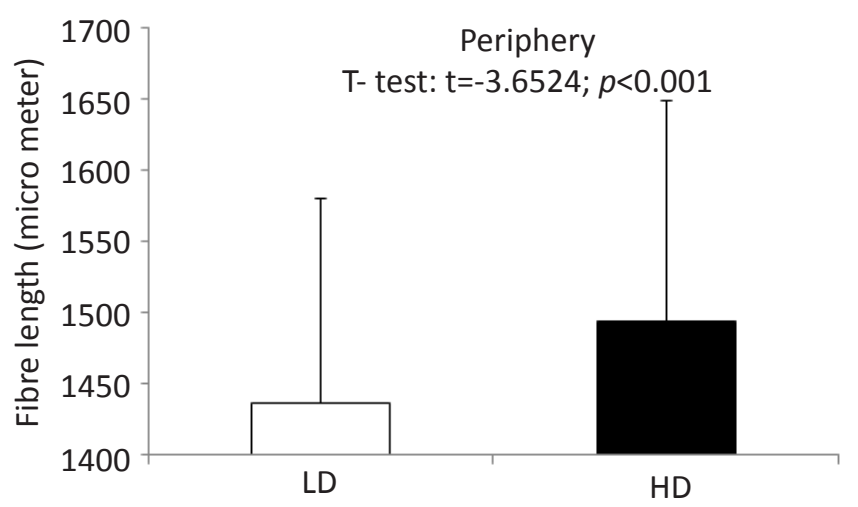

Figure 3: Fibre length of Gymnacranthera canarica wood core samples from different locations

of swamp was pooled. The frequency distribution of fibre length was positively skewed for the less disturbed swamps whereas it was negatively skewed for highly disturbed swamps indicating fibre length increases with increased level of disturbance to swamps (Figure 4). The frequency distribution pattern of two categories of swamps was found to be different using KS test.

Wood fibres are natural composite structures in which cellulose fibrils are held together by lignin and hemicelluloses. The major constituents of wood fibres are lignin, cellulose, hemicelluloses, and extractives. Each of these components contributes to fibre properties, which ultimately impact product properties. The variability in wood characteristics exists within a single tree more than among trees growing on the same site or between trees growing on different sites (Larson, 1967). A large variability was reported for loblolly pine (McGraw 1985) and hardwoods (Koch 1985). Cheng and Bensend (1979) reported using Populus clones, that

Table 3: Fibre length of Gymnacranthera canarica wood core samples from different locations

\begin{tabular}{|c|c|c|c|c|c|c|c|c|c|}
\hline \multirow{2}{*}{$\begin{array}{l}\text { S I. } \\
\text { No }\end{array}$} & \multirow[t]{2}{*}{ Locations } & \multirow[t]{2}{*}{ Wood Core } & \multicolumn{3}{|l|}{ Less disturbed } & \multicolumn{3}{|c|}{ High disturbed } & \multirow{2}{*}{$\begin{array}{c}\text { T-test } \\
\text { Statistics }\end{array}$} \\
\hline & & & Range & Mean & SD & Range & Mean & SD & \\
\hline \multirow[t]{3}{*}{1} & Makutta & Pith & 1608.33-1291.41 & 1452.34 & 088.92 & $1705.56-1295.77$ & 1508.66 & 104.34 & NS \\
\hline & & Middle & 1684.91-1250.69 & 1434.75 & 102.46 & $1700.83-1316.21$ & 1491.97 & 116.22 & NS \\
\hline & & Periphery & $1765.57-1169.17$ & 1400.00 & 109.77 & $1721.26-1316.86$ & 1525.64 & 126.59 & NS \\
\hline \multirow[t]{3}{*}{2} & Sampaje & Pith & $1633.61-1303.18$ & 1461.96 & 090.72 & $1692.47-1333.97$ & 1499.88 & 093.75 & NS \\
\hline & & Middle & $1687.53-1256.36$ & 1437.81 & 126.73 & $1693.95-1168.62$ & 1478.92 & 124.67 & NS \\
\hline & & Periphery & 1688.46-1303.61 & 1477.81 & 110.25 & $1685.11-1283.12$ & 1493.27 & 117.84 & NS \\
\hline \multirow[t]{3}{*}{3} & Thorme & Pith & $1235.28-1676.22$ & 1431.67 & 115.11 & $1258.83-1715.64$ & 1486.73 & 125.70 & $\begin{array}{l}\mathrm{t}=2.66 \\
p<0.02\end{array}$ \\
\hline & & Middle & 1169.41-1672.39 & 1426.23 & 125.8 & $1237.25-1711.30$ & 1473.02 & 152.91 & NS \\
\hline & & Periphery & $1247.86-1753.80$ & 1492.25 & 144.24 & $1049.49-2184.90$ & 1526.28 & 214.98 & NS \\
\hline \multirow[t]{3}{*}{4} & Kathlekhan & Pith & 1164.39-1178.61 & 1470.75 & 128.93 & $1270.07-1647.43$ & 1405.87 & 106.37 & NS \\
\hline & & Middle & $1112.56-1631.07$ & 1361.85 & 139.84 & $1228.56-1589.03$ & 1399.1 & 091.24 & NS \\
\hline & & Periphery & $1065.82-1641.64$ & 1319.84 & 142.54 & $1257.53-1676.89$ & 1453.09 & 131.94 & NS \\
\hline \multirow[t]{3}{*}{5} & Darbejaddi & Pith & $1245.44-1954.00$ & 1545.37 & 189.22 & $1192.44-1814.25$ & 1489.17 & 166.22 & NS \\
\hline & & Middle & $1065.34-1856.41$ & 1510.12 & 167.16 & $1034.06-1634.31$ & 1327.79 & 142.19 & NS \\
\hline & & Periphery & $1113.25-1753.41$ & 1494.76 & 171.83 & $1001.49-1775.61$ & 1401.35 & 308.11 & NS \\
\hline \multirow[t]{3}{*}{6} & Ithalimane & Pith & 1307.84-1684.05 & 1458.86 & 108.78 & 1316.21-1707.34 & 1527.46 & 108.39 & NS \\
\hline & & Middle & $1295.61-1650.03$ & 1460.52 & 93.94 & $1251.19-1678.85$ & 1476.26 & 117.90 & NS \\
\hline & & Periphery & $1304.74-1564.87$ & 1433.26 & 071.95 & 1296.81-1708.35 & 1516.44 & 112.37 & NS \\
\hline
\end{tabular}

Table 4: Fiber length of Gymnacranthera canarica wood core segments from all locations

\begin{tabular}{|c|c|c|c|c|c|c|c|c|}
\hline \multirow{2}{*}{$\begin{array}{l}\text { Sl. } \\
\text { No }\end{array}$} & & \multicolumn{3}{|c|}{ Less disturbed } & \multicolumn{3}{|c|}{ Highly disturbed } & \multirow{2}{*}{$\begin{array}{c}\mathrm{T} \text { - test } \\
\text { statistics }\end{array}$} \\
\hline & & Range & Mean & SD & Range & Mean & SD & \\
\hline 1. & Pith & $1164.39-1954$ & 1470.158 & 130.297 & $1192.44-1814.25$ & 1486.297 & 126.199 & NS \\
\hline 2. & Middle & $1065.34-1856.41$ & 1438.549 & 136.002 & $1034.06-1711.30$ & 1441.179 & 139.281 & NS \\
\hline 3. & Periphery & $1065.82-1765.57$ & 1436.303 & 143.684 & $1001.49-2184.9$ & 1493.797 & 154.782 & $\begin{array}{l}\mathrm{t}=-3.65 \\
p<0.001\end{array}$ \\
\hline
\end{tabular}




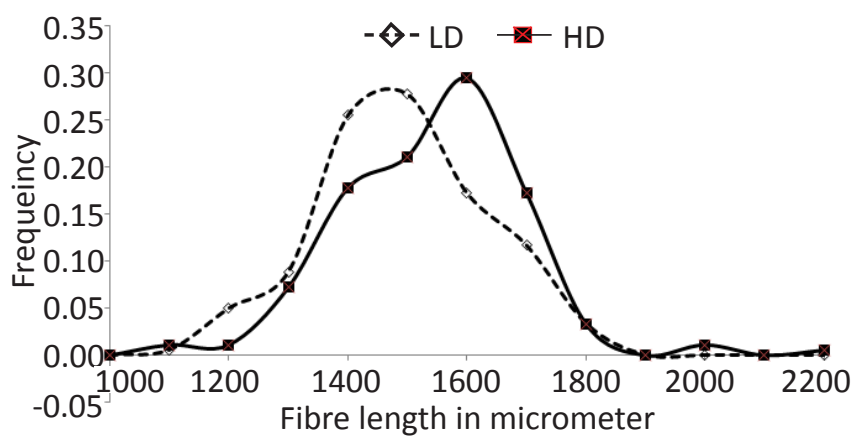

Figure 4: Frequency distribution of fibre length values of Gymnacranthera canarica wood core samples between less disturbed and highly disturbed swamps

the variation in fibre length mainly a result of physiological and environmental factors rather than a genetic factor. The fibre length varies with the age, height and clones have been reported by a number of authors (Bhat. 1990; Chauhan et al., (1999), Yang and Sheng (2003); Pande and Singh, 2009). The horizontal variation in the fibre length has also been reported. The fibre length increases from pith to outwards in some Eucalyptus clones (Ishiguri et al., 2007; Pande and Dhiman, 2010).

In the present study, the fibre length variation was observed. The results indicated there is no significant difference in fibre length in all the locations but it shows a significant difference in periphery region from all the locations. Indicating disturbance may be of recent origin thus has influenced only on periphery region (fibre length). Further, the correlation between fibre length and climatic factors mainly mean annual rain fall and temperature showed no significant relationship. Earlier study has reported that genetic variation in the swampy species is low and thus are genetically more similar (Tambat 2014). Thus, we attribute the variation in fibre length is mainly due to recent years disturbances. Further, if the disturbance persists for several years then results in significant differences in the fibre length of all the wood core segments. Further studies are needed to look into the relationship including the analysis of horizontal and vertical variation within tree.

\section{Conclusion}

Although, the results from four study areas did not show significant difference yet, the study indicates that disturbance influence on wood specific gravity and fibre length of swamp associated tree species. The average values and frequency distribution pattern of specific gravity and fibre length values were significantly different for less disturbed and highly disturbed swamps. In conclusion, the study indicates that disturbance to swamps alters the wood specific gravity and fibre length in swamp associated tree species. Our finding would help in developing long term strategies and action plans for conservation of swamps and its constituent species.

\section{Acknowledgment}

We thank DBT- RGYI, Govt of India, New Delhi for financial support. BP Conservation Society, UK (Conservation Leadership Programme). Karnataka Forest Department is greatly acknowledged for the permissions. IWST, Bangalore for laboratory facilities. We also thank Mr. Sanaulla and Mr. Shangundu for their help and assistance during the field visit.

\section{References}

Anonymous, 2000, Red-listed Medicinal Plants of Karnataka, FRLHT, Bangalore, India.

Bhat, K.M., 1990, Wood quality improvement of eucalyptus in India : An assessment of property variations. Journal of Indian Academy Wood Sciences 21(2), 33-38.

Chaithra, G.N., Tambat, B., Prasanna, N.S., Srinivas, C., 2014. Demographic status of Midimaavu in Chikmagalur district, central Western Ghats, India. The Indian Forester 140 (11), 1131-1136.

Chauhan, L., Raturi, R. D. and Gupta, S., 1999, Studies on anatomical variations in different clones of Populus deltoides. The Indian Forester 125, 526-532.

Cheng, W.W.D., Bensend, W., 1979. Anatomical properties of selected Populus clones grown under intensive culture. Wood Science, 11(3), 182-187.

Ferraz Filho, A.C., Barbara, C.B., Leckie, U., 2011, Dominant height projection model with the addition of environmental variables. CERNE, 17, 34-61.

Ganesan, R., 2002. Evergreen freshwater swamps and their plant species diversity on Kalakad-Mundanthurai Tiger Reserve (KMTR), south Western Ghats, India. The Indian Forester, 12, 1351-1359.

Gilmore, R.W., 1968. From Military Keynesianism to Post Keynesian Militarism., Ph. D. Thesis, The State University of New Jersey, New Brunswick.

Ishiguri, F., Eizawa, J.Y. Saito., K., lizuka, S., Yolota, D., Priadi, N., Sumiasri and Yoshizawa, N., 2007. Variation in the wood properties of Paraserianthesis falcataria planted in Indonesia. IAWA Journal, 28(3), 339-348.

Josefina, B.M., 1987. Wood specific gravity in species from two tropical forests in Mexico. IAWA Bulletin, 8(2), 143-148.

Keays, J.L., 1971. Complete- tree utilization- An analysis of the literature. Part I, Unmerchantable top to bole. Can. Dep. Fish. For. Can. For. Serv. For. Prod. Lab. Vancouver, Inform. Rep. VP-X-69.98.

Koch, P., 1985. Utilization of hardwoods growing on southern pine sites. Agr Hand No.605 I. The raw material, II. Processing, III. Products and Prospective. US for Serv, Washington C, 3710.

Larson, P.R., 1967, Effects of temperature on the growth and wood formation of ten Pinus auriculiformis. Quarterly Journal of the Experimental Forest of National Taiwan,

Myers, N., Mittermeier, R.A., Mittermeier, C.G., Fonseca, G.A.B., Da Kent, J., 2000. Biodiversity Hotspots for Conservation Priorities. Nature 403, 853-858.

McGraw, R.A., 1985. Wood quality factors in loblolly pine. Tappi Press, Atlanta, Georgia, 89. 
Nicholls, J.W., 1967. Assessment of wood qualities for tree breeding IV. Pinus pinaster grown in Western Australia. Silvae Genetica 16, 21-28.

Pande, P.K., Dhiman, R.C., 2010. Variations in wood traits in micro and macro propagated plantation woods of Populusdeltoides Bartr. ex Marsh. Advances in Biosciences and Biotechnology 1(1), 30-38.

Pande, P.K., Singh, M., 2009. Individual tree, intra- and interclonal variations in wood properties of the clonal ramets of Eucalyptus tereticornis Sm. The Indian Forester 135(5), 629-646.

Ponnamperuma, F.N., 1984. Effects of flooding on soils. In: T.T. Kozlowski (Ed.) Flooding and Plant Growth. Academic Press, Orlando, San Diego, 10-45.

Ramesh, B.R., Pascal, J.P., 1997. Atlas of the Endemics of the Western Ghats (India). French Institute, Pondicherry.

Schmidtling, R.C., Amburgey, T.L., 1982. Genetic variation in decay susceptibility and its relationship to growth and specific gravity in loblolly pine. Holzforschung 36 (3), 159-161

Sluder, E.R., 1970. Variation in wood specific gravity of yellow poplar (Liriodendron tulipifera) and its relationship to environmental conditions in the Southern Appalachians. Ph. D. Thesis, North Carolina State Univ. Raleigh, North Carolina.

Smith, D.M., 1954. Technologist, Maximum moisture content method for determining Specific Gravity of small wood samples. A manual of Forest Products Laboratory, Forest Service U. S. Department of Agriculture Report No 2014.

Suzuki, E., 1999. Diversity in specific gravity and water content of wood among Bornean tropical rain forest trees. Ecological Research 14, 211-224.

Tambat, B., Chaithra, G.N., Vasantha Reddy, K.V., Vasudeva, R., Ganeshaiah K.N., Uma Shaanker, R., 2012. Threat Assessment of Myristica swamps in central Western Ghats. International Journal of Forest Usufructs and Management 13(2), 3-12.
Tambat, B., Chaithra G.N., Uma Shaanker, R., 2014. Myristica Swamps: An Unique and Threatened Ecosystem of Western Ghats Distribution, Ecology, Phylogeny, Population Genetics, Fitness and Threats, Lambert academic publishing, 2014.

Tambat, B., Vishwanath, K., Chaithra, G.N., Gunaga., R.P., 2007. A report on seed abnormality in Gymnacranthera farquhariana Hook. F. and Thomson (Myristicaceae): An endangered swampy species of Western Ghats, India. The Indian Forester 8, 1075-1080.

Varghese, A.O., Menon, R.R., 1999. Floristic composition, dynamics and diversity of Myristica swamp forests of southern Western Ghats of Kerala. The Indian Forester 125(8), 775-783.

Vasudeva, R., Raghu, H.B., Dasappa, Uma Shaanker, R., Ganeshaiah, K.N., 2001. Population structure, reproductive biology and conservation of Semecarpus kathalekanensis: a critically endangered freshwater swamp tree species of the Western Ghats. In: Forest Genetic Resources: Status, Threats and Conservation Strategies. Uma Shaanker, R., Ganeshaiah, K. N. and Bawa, K. S. (eds). Oxford and IBH Publishing Co. Pvt. Ltd., New Delhi, 211-223.

Vijendra Rao, R., Dayal, R., Raturi, R.D., 1992. Wood anatomy of Indian Myristicaceae with critical remarks on some foreign genera. The Indian Forester 112, 125-141.

Yang, W.Z., Fang Sheng, Z., 2003. Variation of fiber length and fiber width for sevenpopular clones. Journal of Nanjing Forestry University, 27 (6), 23-26.

Zobel, B.J., Van Buijtenen, J.P., 1989. Wood variation: its causes and control: Springer, Verlag, Berlin, 363.

Zobel, M., 1989. The relative role of species pools in determining plant species richness: an alternative explanation of species coexistence. Trends in Ecology and Evolution 12, 266-269. 